\title{
COMPETING ROLES OF THE NATIONAL LANGUAGE AND ENGLISH IN MALAYSIA AND THE PHILIPPINES: PLANNING, POLICY AND USE
}

\author{
Francisco Perlas Dumaniga , Maya Khemlani David and Lorraine Symaco \\ University of Malaya
}

\begin{abstract}
This paper examines the impact of language planning and language policy in the competing roles of the national language and English in the educational system of Malaysia and the Philippines. These countries have emphasised the national language (i.e. Malay in Malaysia and Filipino in the Philippines) to foster national unity, and the international language-English for global communication. Educational expansion as documented with globalisation has also repositioned the role of the English language. While English has become a necessary tool to increase competitiveness in the global market, calls to 'switch back' or 'retain' the national language to instil a sense of national unity has also been equally advocated. Although planning and policy may have specific objectives, these may not be reflected in actual language use. The findings of this study reveal the social reality of contrasting language planning and policy initiatives in Malaysia and the Philippines and the actual use of these languages.
\end{abstract}

\section{Language Policy and Globalisation}

Educational expansion is documented globally in line with the rising call for internationalisation and globalisation of services (Symaco, 2011; Shoefer \& Meyer, 2005). Relevant to this expansion of educational services is the rise of globalisation which similarly dictates the circumstance besetting educational institutions. Globalisation is one of the more prominent features of the modern world and also relevant to the increasing access to educational services in the world at large. Various definitions of globalisation in general have been suggested and Beerkens (2003, p.130) summarises a few approaches in an effort to define globalisation. The different conceptualisations inherent in globalisation which are to be discussed are said to be distinctive through the points of reference of their 'past' and 'new' realities. That is to say a shift in 'type' from one stage to the other due to historical, political and cultural changes.

With reference to the above definitions, economic trade through capitalist growth provides the basis for the worldwide expansion which marks out the 'global' from the local. The nation state is thus viewed as part of a world system of nation states, and, in globalisation, the strengthening of this process of interconnectedness and the simultaneous evolution and erosion of the nation state can be observed. The second concept of authority or power informs the capacity of governments for international competition. The change of power or authority defines the "deterritorialisation" of states (Beerkens, 2003), which in their past realities are limited to clearly defined areas of regulated space. The third conceptualisation of 'global' in terms of culture associates globalisation with the integration of traditions and customs. A considerable argument has been made over the imbalanced

a

Correspondence can be directed to: francisco@um.edu.my

Journal of International and Comparative Education, 2012, Volume 1, Issue 2

ISSN 2232-1802 
pre-eminence of Western traditions over others (Huntington, 1996). The last concept provided in this definition is that of the institution and the achievement of a cosmopolitan identity. The main contention of this argument is that social interconnectedness is no longer dependent on longstanding national institutions, but rather on a broad-based and 'multinational' cohesion. Hoogvelt (1997) further refines and amends the geographical partition into 'social' core and periphery. The interconnectedness found between the global world and the individual society, and the social consciousness as illustrated, among other things, in the growing awareness of sustainable development as exemplified in the Brundtland Report (WCED, 1987) shows this.

Globalisation as described through the four concepts above also informs the continuing and altering interconnected relations brought about by changes in society through advancement in communications, knowledge and market transformations. This notion can be seen in the evolution of the education systems through internationalisation, cross-border education, and technical capacity-all of which bring to fore the use of the English language as a 'necessary tool' for the assumed interconnections.

Language planning, policy and use play an important role in an ever increasing knowledgebased society. Through language planning, a policy formulated can affect the language use of individual speakers. Language policies influence the behaviour of others, particularly in the acquisition, structure, or functional allocation of their language codes (David, 2009) and further influence the speakers' language choice and use in social, educational, political, or economic domains. This is particularly relevant in terms of achieving the cosmopolitan identity through the 'multinational' cohesion as exemplified by globalisation. This point is especially relevant to Malaysia, a country composed of three main ethnicities (ie Malay, Chinese and Indians) with corresponding 'local' languages, and the Philippines, an archipelagic state with an eclectic mix of local dialects/languages totalling to about 160, spread across over a hundred different ethnicities (Watson, 2011). However, the pre-eminence of Western standards as espoused by globalisation and reflected through language use (both the English language in the Philippines and Malaysia) is countered by rising calls of nationalism and the need to 'preserve cultural identity', the politics behind such agenda also imminent in some countries.

Language serves as a powerful tool and expanding further Bourdieu's 'habitus/ cultural capital' approach-- issues brought about by language policies in educational access, among others are evident. But despite the desired unification and interconnectedness that language policies (often time the use of a preferred language) are proposed to bring, inequity issues are present since language policies can possibly "cause a further divide among ethnic groups where the language of the dominant group (usually the formal colonial power) is preferred in modern business of technology" (Symaco, 2010, p.266). Watson (2007) further states that globalisation often aggravates the problem through the move to uniformity of curricula and "the adaptation of a universal rather than a multilingual medium of instruction" (ibid, 2010, p.266). Advocates of regional languages/dialects also caution of the failure to preserve local knowledge and culture on this move for uniformity. This is also of course reflected in educational policies which favour certain languages to be used as medium of instruction, some of which claim to promote 'better learning' over others.

Over time, the changing scenario on the national front in both countries and on the global scene and the resultant opening of national borders have influenced language policies. Nationalism through language use has to deal with competition and the need for proficiency in English as the language for global communication, science and technology. The use of English as international 


\section{COMPETING ROLES OF THE NATIONAL LANGUAGE AND ENGLISH IN MALAYSIA AND \\ THE PHILIPPINES: PLANNING, POLICY AND USE}

language and language of globalisation and modernisation has brought a number of challenges in the language planning and language policy. The sections to follow will trace the historical background of the language policies in Malaysia and the Philippines and examine relevant language policies and practices in both countries in line with the issues discussed above.

\section{The Philippine Language Policy: Top- Down Policy}

The Philippines, as mentioned earlier, has about 160 languages spread across over a hundred ethnic groups. The Philippine Bilingual Education Policy in 1974 (revised in 1987) states that English and Filipino are the languages of education and the official languages of literacy. The implementation of the bilingual policy was to make its people bilingual, capable of communication both in English and Filipino. Consequently, such policy has contributed to the abandonment of minority languages in the Philippines (Jernudd, 1999; Grimes, 2000; Young, 2002; Kaplan \& Baldauf, 2003; Nical, Smolicz \& Secombe, 2004). Under the policy, the Filipino language was used as the medium of instruction (MOI) in schools at the primary level. In schools where Filipino is not used, the use of vernacular language is permitted in the lower grades (i.e. grades one to four, ages 7-10) and Filipino is used as $\mathrm{MOI}$ in the fifth grade. In this case, since Filipino and English are not taught in the lower grades, they are taught as double period subjects in grades five and six. At the secondary level (ages 13 to 16) both English and Filipino are used as the media of instruction (Fonacier, 1987, p.145).

In light of the need to give importance to the vernacular language, a new policy in 1973 was implemented wherein the vernacular language is to be used as $\mathrm{MOI}$ at the primary level (i.e. grades one to two). However, such an attempt was not successful and the policy was revised by allowing English and Filipino as $\mathrm{MOI}$ in all levels and using the vernacular only as an auxiliary language (Llamzon, 1977; Fonacier, 1987). The 1987 Philippine constitution (Article 14, Sec. 6) states that,

The national language of the Philippines is Filipino (...) the Government shall take steps to initiate and sustain the use of Filipino as a medium of official communication and as language of instruction in the educational system.

Further Section 7 of the Constitutions states that,

For purposes of communication and instruction, the official languages of the Philippines are Filipino and, until otherwise provided by law, English. The regional languages are the auxiliary official languages in the regions and shall serve as auxiliary media of instruction therein (...).

It is evident from the Article Sections above that the Filipino language is to be used as the medium of communication and instruction in the country's education system at all levels (primary to tertiary). The vernacular language in this case shall be resorted to only when necessary to facilitate understanding of the concepts being taught through the prescribed MOI: English or 
Filipino (DECS order no 25, cited in Sibayan, 1985). Given the variety of languages existing in the Philippines, this policy provides opportunity to enhance and develop the national language. Additionally, there is provision for the use of English and regional languages in the educational system, though Filipino is still given much priority. Allowing other regional languages to be used as auxiliary languages is also a wise option because it helps in the maintenance of ancestral languages.

However, of late, the Philippine government has shifted back to the promotion of the vernacular/mother tongue (i.e., not necessarily Filipino given the variety of languages/dialects in the Philippines) in schools when the Department of Education (DepEd) institutionalised the Multilingual Education (MLE) initiative in 2009 which aims to promote the use of mother tongue/first language over the second language, supposedly to promote better learning among the students. The government believes that students will learn better if such multilingual approach is applied. Under this scheme, two languages for instruction are used and policy enactment stems from the results of the Lingua Franca Education Project (LFEP) of 1999 and the Lubuagan First Language Component.

The LFEP was an experimental project for Grade 1 students (age 7) which aims at that time to "define and implement a national bridging program from the vernacular to Filipino and later English to develop initial literacy for use in public schools" (DECS Memo 144, 1999, p.1). The MLE was fully implemented in 2012 in all public schools with emphasis given to kindergarten and grades 1 to 3 (i.e. ages 5 to 9). This policy is also in line with the Department of Education's policy of 'Every child a reader and a writer by grade 1 '. About 900 schools including those with indigenous peoples have been modelling the MLE prior to the full implementation order of 2012, which used 8 languages in the roll-out. It should be noted that in multilingual Philippines the mother tongue is not necessarily the Filipino language.

The MLE is featured in two modes: (a) as medium of instruction and (b) as a learning subject/school course. It further states that:

The learners' mother tongue (L1) shall be used as the medium of instruction (MOI) in all domains/learning areas from Kindergarten through Grade 3 except [for school subjects] Filipino (L2) and English (L3). The L1 will continuously be used as $\mathrm{MOI}$ in a transition or bridging process through (L1-L2-L1 or L2- L1-L2) Grade 3. The L2 will be introduced in the first semester of Grade 1 (...) and continuously developed from Grades 2-6. Oral fluency in L3 will be introduced in the $2^{\text {nd }}$ semester of Grade 1 (...) [other] macro-skills will be developed starting $2^{\text {nd }}$ semester of Grade 2 until 6 (DepEd Order 16, 2012, p. 3)

\section{Mismatch Policy and Practice: Bottom-Up}

The Philippines places importance to its national language as exemplified, among others, in the inclusion of an annual nationwide celebration of "Linggo ng Wika" (Language Week) in schools to instil in students the significance of the national language for development.

However, the Sections in the 1987 Constitution as earlier discussed are not evident in practice in some educational institutions (basic to higher education levels). English is widely used and preferred in campuses despite the top down language policy in the Philippines which clearly advocates the need to promote and preserve the Filipino language. The 1987 Constitution (Article 14 Section 9) states that "the Congress shall establish a national language commission (...) for the 


\section{COMPETING ROLES OF THE NATIONAL LANGUAGE AND ENGLISH IN MALAYSIA AND \\ THE PHILIPPINES: PLANNING, POLICY AND USE}

development, propagation, and preservation of Filipino and other languages." Countervailing the "Linggo ng Wika" celebration is the "Speak English" campaign in schools. Instead of enhancing the Filipino language in schools, English appears to dominate. Mismatch between policy and practice is documented (Gonzalez, 2003) and despite the clear mandate of the Filipino language as the official language of instruction in educational institutions, its subordinate status when compared to the English language is apparent.

English continues to dominate in classroom instruction and interviews with students reveal the preference of the English language given its 'social and economic' benefits.

"If I master the English language, I will have more chances of getting a job after graduation ... for example working in the call centre"

"If Filipino is given priority in school then I'll find another school that gives importance in English"

"I study to learn and to learn English so I can work abroad"

"If we can't speak English well we cannot find better job"

"Most companies hire applicants with good command of English"

"English is an international language and recognised all over the world while Filipino is only used in the Philippines"

The demand for the English language is supported by various stakeholders given that its acquisition would mean better opportunities for job securement, both locally and overseas. The massive migration of skilled and unskilled workers from the Philippines is documented by the 16.2 billion US Dollars as workers' remittances and compensation of employees in 2010 alone (World Bank, 2012). This explains why institutions offering training in English is favoured by the general public and draws in rough how the Filipino language is advocated to develop a stronger sense of nationalism while preference is given to the English language by most, given its ability to open doors for better opportunities.

The use of the English language as means to act as a tool for 'interconnectedness' is however pursued by some as constructed colonialism (Pennycook, 1998). English evidently in the Philippines is used as a social tool that enables economic advancement, and the feature of Englishcompetent society where political-economic elites usually emerge (Tupas, 2003) all draw above in rough the colonial and imperialist feature of the language still advocated by some. The line of reasoning that development and nationalism cannot 'go together', though rather sweeping, was argued by Sta. Maria about a decade ago that the Philippines must "set aside at this critical period of our development (...) over-zealous feelings of nationalism, which deter our efforts at improving the teaching of English" (ibid p.12). This usual measure of nationalism to language use during the debate of the bilingual policy however now has been taken over by an overriding theme that cognitive development improves significantly if the first language is used in instruction, with the socio-cultural aspect of national pride evidently still emphasised in the discourse but not necessarily taking precedence. Despite the increasing call to internationalise and the move towards promoting the English language in the country, advocates of the effectiveness of using the mother tongue as the medium of instruction for schools are now reviving the call to promote the "local" language. The institutionalisation of the mother tongue based multilingual education (MLE) reflects this, 
notwithstanding the costs to be incurred for promoting such policy. This is of course promoted with the intention, as always, of the Philippine government to achieve the Education for All (EFA) goal in 2015.

\section{Language Policy in Malaysia: Top- Down}

In colonial Malaya, English was the official language and Malay, Chinese and Tamil languages were deemed vernaculars. There were Malay intellectuals who rationalised that English in colonial Malaysia "produced a detrimental effect on the development of the Malay language [as it was] confined as the language of the home and the medium of instruction of a limited number of primary schools, Malay was deprived of the opportunity to develop" (Karim, 1981, p. 45). It would therefore be timely to "release the Malay from the shackles of British colonialism which was best represented in the vestiges of the English language" (Mitchell, 1993, p. 61). While there may be some truth to what the Malay nationalists and intellectuals felt about the development of Malay language and indigenous rights, the rationalisations remain rhetoric because the compelling reason for the accelerated use of Malay especially in education, according to Watson (1983), was to some extent based on the belief that the non-Malays had done well in English medium schools and at tertiary institutions. The English educated urban non-Malays had dominated major commerce/ business sectors as well as the professions while the largely rural Malay population had been by-passed.

With the coming of independence in 1957, the leaders of the major communities decided to accept Malay as the national language, a symbol of national unity. According to Omar (1997), Malay was chosen to fulfil this function because of

Its indignity, its role as a lingua franca, its position as a major language, its possession of high literature, and the fact that it once had been an important language of administration and diplomacy in the Malay archipelago (p.15).

Malay was therefore accepted as the national language and a symbol of national unity although peculiarly, as Gill (2004) states less than 50 per cent of the population at that time spoke Malay.

Even before independence, political parties like the United Malays National Organisation (UMNO) and the Malaysian Chinese Association (MCA) had agreed that Malay would be the national language via a memorandum in August 1953. Thus there was little controversy over the acceptance of Malay as the national language and this has been confirmed by Article 152 of the Malaysian Constitution. However, the Constitutional framers did not phrase Malay as the "official" language, a stamp that allows the language to be used for all official purposes. Consequently from 1957 to 1967, English continued to fulfil this official role and would have continued unabated but for the rise in linguistic nationalism among Malay nationalists.

After independence, the leaders of the country chose to progress along a pragmatic path, pacifying minority communities of the continued role for their languages and at the same time assuring Malay nationalists of a greater role for Malay. At this time it was apparent that the nationalists would not accept the notion of a multilingual nation. Discontented Malay nationalists were unhappy with the slow progress in the institutionalisation of Malay in the country and sought to champion Malay in political domains (vis-à-vis the official language, the language of administration, education and for all formal and official purposes) (David \& Govindasamy, 2003). 


\section{COMPETING ROLES OF THE NATIONAL LANGUAGE AND ENGLISH IN MALAYSIA AND THE PHILIPPINES: PLANNING, POLICY AND USE}

The Malay groups, particularly the powerful Federation of Malaya School Teachers' Association and the Malay National Action Front, were also unhappy with the provisions of the 1967 National Language Act and criticised it as not enhancing the status of Malay as the primary language of the nation because the Act asked for the continued use of English (Mitchell, 1993). The opposition to the continued use of English is understandable as Chai (1971) observes,

English came to be regarded not only as the language of colonial education but also, after independence, as an obstacle to the educational, social and economic advance of the majority of Malays (p. 61).

Their suspicion was confirmed by an important fact: there was a steady increase in enrolment in English medium secondary schools (Watson, 1983).

The Ketuanan Melayu ideology (or Malay supremacy), that spurred nationalists to promote and encourage Malay language was also highlighted in the former Prime Minister, Mahathir Mohamad's book, the Malay Dilemma- which is not surprising as Mahathir was a strong proponent of strengthened affirmative action for the Malays. Mahathir, in his highly one-time controversial book wrote that the Malays are the "definitive people" of Malaysia as they have a birth right guaranteeing them special privileges such as those outlined by Article 160 of the Constitution of Malaysia. The Article states that a Malay is one who professes to be a Muslim, habitually speaks the Malay language, adheres to Malay customs, and is domiciled in Malaysia (Shuid \& Yunus, 2001). There were Malay nationalists who viewed that having other languages in educational domains were detrimental to the nation's unity. For instance, Syed Nasir Ismail, a Malay nationalist political leader during that period, insisted on closing down all Chinese schools in Malaysia as soon as possible, in order to make Malay the sole official language and to reduce competition (Lee, 2001).

The Malay language policy as a medium of instruction was implemented and vernacular schools at least until primary level were allowed to remain. In order to enable students from vernacular schools to effectively transfer to Malay medium secondary schools, transitional classes called Remove Classes were introduced in 1960 by the Rahman Talib Report. Pupils from Chinese, Tamil and at that point in time Malay medium primary schools, were required to undergo an extra year in these "remove classes" in the secondary school. This was to enable students from vernacular schools to become proficient in Malay or English as the situation required. With independence in 1957 and the consequent need for nation building, Malay was made the national language of the country in 1967.

The Malay nationalist leaders also took the opportunity to assert that Malay should be used as a lingua franca to promote unity amongst the ethnic groups as it is stated in the Federal Constitution (Article 153) that Malay is the national language of Malaysia. Malay thus was seen as an identity that is shared by all Malaysians; hence it was only appropriate to learn it in order to be considered Malaysian.

The leaders, spearheaded by the ruling government party-- Barisan Nasional (National Front), jointly agreed to reduce the influence of English as it was associated then with British imperialism. In the process, English schools were converted to the Malay-medium in West Malaysia by 1983 (Omar, 1993), while English schools in Sabah and Sarawak (East Malaysia) were converted by 1985 (Solomon, 1988, p.46). The conversion of the English medium schools to Malay medium 
began in 1968 at a gradual pace and on a piecemeal basis (Solomon 1988, p.47). Initially, those subjects that could adopt the Malay language as a medium of instruction without difficulty were the first affected by the conversion process (Omar 1982, p.15). From January 1968, all English medium primary schools were required to teach physical education, art and craft, local studies and Music in Malay in years 1, 2 and 3. Most of the Arts subjects were taught in Malay before the shift to Malay occurred for the Science subjects. In fact for a short period of time during this transitional phase, some schools ran the same course in science subjects in two streams, namely, Malay and English. By 1976, all English medium primary schools were completely converted into schools where Malay was used as the medium of instruction and by 1982 all the former English medium secondary schools were converted to National Schools in Peninsular Malaysia (Solomon, 1988, p.46). The Education Act was extended to Sarawak in 1977 and the change of the medium of instruction to Malay throughout the entire school system was completed in Sabah and Sarawak three years later, i.e. by 1985.

To redress the imbalance, education was chosen as the primary mode for instituting changes. The language policy changes that came into effect in the country in the 1970s included:

- Malay replacing English as the medium of instruction in all English medium primary and secondary schools. This task was completed in 1978.

- all university education being conducted in Malay. This exercise was to be completed in 1983 but in actual fact took longer because of teething problems.

- the Higher School Certificate (A- level) and School Certificate (O-level) examinations as well as other national examinations being offered in Malay. The A- and O-level examinations were replaced by Malaysian Higher School Certificate (STPM) and the Malaysian Certificate of Education (SPM), respectively.

- most importantly, students having to obtain a credit in Malay to be awarded the SPM certificate; the prerequisite to obtaining a tertiary education, government jobs, teacher training opportunities, among others.

In addition to the above mentioned educational policies, the setting up of other completely Malay-based institutions such as the MARA Institute of Technology, junior science colleges, a large number of residential science schools and almost unlimited funding for Malay scholars as well as the preferences in employment in the public sector can be classified as affirmative action designed to ensure the correction of the ethnic socio-economic disparity existing in the country. This wideranging affirmative action was expected to bring about outcomes that could truly empower the Malays vis-à-vis the other communities.

\section{Mismatch Policy and Practice: Bottom- Up}

As English proficiency deteriorated in Malaysia (as compared to the proficiency of those who graduated from English medium schools during the British era) despite the language being declared the second most important language in Malaysia, more and more local graduates found it difficult to secure jobs. Twenty years after the implementation of Malay-medium education throughout the schools and tertiary system, due to the processes of globalisation, the leaders of the country realised that the fortification of the Malay language at the expense of the development of English was detrimental to its people. In early 2002, it was reported in the major newspapers that 


\section{COMPETING ROLES OF THE NATIONAL LANGUAGE AND ENGLISH IN MALAYSIA AND \\ THE PHILIPPINES: PLANNING, POLICY AND USE}

there were 24,000 unemployed graduates from the Malay community (The Star, 6 May 2002). It was also reported that many were unable to procure jobs because of their limited English language skills. Students' English language proficiency nosedived and graduate unemployment, particularly among Malays, peaked and was acute enough for some quarters to demand a re-examination of the language policy (see David, 2004). One such group was private-sector employers; for example, the Malaysian Employers Federation Executive Director, Shamsuddin Bardan, who explained, "employers were reluctant to hire local graduates because they were not able to communicate well in English...This is one of the reasons there are so many unemployed Bumiputra ${ }^{1}$ graduates" (The Star, 2002a, p.4).

Fluency can result from inter-ethnic socialisation. Government policies must encourage such socialisation. Networking and socialising with Malays proved to be a useful strategy in acquiring Malay for many non-Malays. Similarly, interacting with non-Malays provided some Malays the opportunities to use English. If a community or ethnic group is not given the opportunity to interact, this can also limit the acquisition and use of a target language, be it Malay or English. In this regard, the New Economic Policy (NEP) that aimed to create a large middle class of ethnic Malays to some extent, helped in the acceptance of English. This is because as a result of the NEP, many Malaysians who were provided scholarships to study abroad were exposed to English and their acquisition of English increased in such settings. They studied abroad for a number of years and on returning to Malaysia still use/d English, especially in private sector jobs (David \& Govindasamy, 2003).

Teacher and family support gives the target language a transactional value, thus creating extrinsic motivation to learn the language, provides a wider environment for target language use, and policies and practices which encourage cross-ethnic interaction, are all important factors which help in the acceptance of new language policies and help to minimise inequalities, which changes in language policies may cause.

\section{Conclusion}

The competing roles of English and national language in language planning and use in two countries, Malaysia and the Philippines is evident. Both policies emphasise the importance of the national language (i.e. Malay and Filipino) and mandate both as the medium of instruction in schools. However, in the actual use of the language, English dominates because of its economic and social benefits. Such competing roles can hardly be resolved due to the increasing popularity of globalisation where English continually dominates. Nationalistic groups in both countries have recurrently highlighted the significance of using the relevant national language to instil national unity needed for development. The re-examination of language policies in both countries that will balance the importance given to the national language - to instil national unity, and English-for greater involvement in the move towards globalisation is recommended.

\section{Notes}

${ }^{1}$ Bumiputra is a term used to describe Malays and indigenous people in Malaysia 


\section{References}

Beerkens, K. (2003). Globalisation and higher education research. Journal of Studies in International Education, 27 (2), 128-148.

Chai, H.C. (1971). Planning education for a plural society. Paris: UNESCO, International Institute for Educational Planning.

David, M. K. \& Govindasamy, S. (2003). Language education and 'nation building' in multilingual Malaysia. In J. Bourne and E. Reid (Eds.) Language Education: World Yearbook of Education 2003. London: Kogan Page.

David, M. K. (2004). Language policy changes in multiracial Malaysia: Effects and coping strategies. Studies in Foreign Language Education, 18, 33-50.

David, M.K. (2009). Moving beyond schema: Selecting texts for EFL readers. In C. Andrzej (Ed.). Extensive Reading in English Language Teaching. Poland: Polish Scientific Publishers PWN.

DECS (1999). Memo 144 The mother tongue-based multilingual education project in SY 19992000. Pasig: DECS

DepEd (Department of Education) Order 16 (2011) Guidelines on the implementation of the month tongue-based multilingual education. Pasig: Deped

Fonacier-Bernabe, E. J. (1987). Language policy formulation: Programming, implementation and evaluation in Philippine education. Manila: Linguistic Society of the Philippines.

Gill, S. K. (2004). English language policy in Malaysia: Demystifying the diverse demands of nationalism and modernisation. In Saran Kaur Gill (Ed.). Special issue on the English language situation in Malaysia: Policy, nativisation and standards. Asian Englishes, $6(2)$.

Gonzales, A. (2003). The role and contribution of the Thomasites to language education. In D.V. Corazon (Ed.) Back to the future: Perspectives on the Thomasite legacy to Philippine education. Manila: American Studies Association of the Philippines and Cultural

Affairs Officer US Embassy.

Grimes, B. F. (Ed.) (2000). 'Pakistan'. In Ethnologue: Languages of the World (14 ${ }^{\text {th }}$ Edition) Dallas, Texas: Summer Institute of Linguistics.

Hoogvelt, A. (1997). Globalisation and the post-colonial world: The new political economy of development. Basingstoke: Macmillan.

Huntington, S. (1996). The clash of civilizations and the remaking of world order. New York: Simon \& Schuster.

Jernudd, B. (1999). Language education policies - Asia. In B. Spolsky (Ed.). Concise encyclopedia of educational linguistics. Amsterdam: Elsevier.

Kaplan, R.B. and Baldauf, Jr. R.B. (2003). Language and language in education planning in the Pacific Basin. Dordrecht: Kluwer.

Karim, N. S. (1981). Bahasa Malaysia as a medium of instruction in a modern, plural society. In A. H. Omar \& N.E. Mohd. Noor (Eds.). National language as medium of instruction. Paper presented at the Fourth Conference of the Asian Association on National Languages (ASANAL)

Lee, K. Y. (2000). From third world to first: The Singapore story: 1965-2000. New York: Harper Collins. 


\section{COMPETING ROLES OF THE NATIONAL LANGUAGE AND ENGLISH IN MALAYSIA AND THE PHILIPPINES: PLANNING, POLICY AND USE}

Lee, D. (2001). Cognitive linguistics: An introduction. Oxford: Oxford University Press. Llamazon, T. A. (1977). A requiem for Pilipino. In B. Sibayan and A. Gonzalez (Eds.). Language planning and the building of a national language. Manila: Linguistic Society of the Philippines and Language Study Centre, Philippine Normal College.

Mitchell, R. W. (1993). Mental models of mirror-self-recognition: Two theories. New Ideas in Psychology, 11, 295-325.

Nical, I., Smolicz, J.J. \& Secombe, M.J. (2004). Rural students and the Philippine bilingual education program on the island of Leyte. In J.W. Tollefson and A.B.M.Tsui (Eds.). Medium of instruction policies: Which agenda? Whose agenda?. Mahwah, NJ: Lawrence Erlbaum Associates.

Omar, A.H. (1982). Language and society in Malaysia. Kuala Lumpur: Dewan Bahasa \& Pustaka. Omar, A.H. (1993). Perancangan bahasa dengan rujukan khusus kepada perancangan Bahasa Melayu. Kuala Lumpur: Dewan Bahasa \& Pustaka.

Omar, A.H. (1997). A discussion of the path taken by English towards becoming a Malaysian language. In M.S. Halimah \& K.S. Ng (Eds.). English is an Asian language: The Malaysian context. Kuala Lumpur: Persatuan Bahasa Modern Malaysia.

Pennycook, A. (1998). English and the discourse of colonialism. London: Routledge.

Rahman Talib Report (1960). National Education Policy in the Razak Report on the education system in the Federation of Malaya.

Shoefer, E. \& Meyer, J. (2005) The world-wide expansion of higher education in the twentieth century. American Sociological Review, 70 (6). 898-920.

Shuid, M. \& Yunus, M. F. (2001). Malaysian Studies. Kuala Lumpur: Longman.

Sibayan, B.P. (1985). Bilingual education in the Philippines: Strategy and structure. In J. Alatis (Ed.). International Dimensions of Bilingual Education. Paper presented at Georgetown University Round Table in Languages and Linguistics, 1978. Washington, DC: Georgetown University Press.

Solomon, J. (1988). Bilingual Education. Kuala Lumpur: Pelanduk.

Symaco, L.P. (2010). Higher education and equity in Malaysia. The International Journal of Educational and Psychological Assessment, 5 (2), 265-272.

Symaco, L.P. (2011). Philippines: education for development? In C. Brock \& L.P. Symaco (Eds.). Education in South East Asia. Oxford: Symposium Books.

The Star (6 May 2002). English anyone? Available at: http://thestar.com.my/. [Accessed 15 June 15 2010].

The Star (2002a). English anyone? Available at http://thestar.com.my/. [Accessed 3 July 3 2010].

Tupas, R (2003) history, language planners, and strategies of forgetting. Language Problems and Language Planning, 27(1), 1-25.

Watson, K. (1983). Cultural pluralism, national building and educational policies. In C. Kennedy (Ed.) Language Planning and Language Education. London: George Allen \& Unwin.

Watson, K. (2007). Language, education and ethnicity: Whose rights will prevail in an age of globalisation? International journal of Educational Development, 27(3), 252-265.

Watson, K. (2011). Education and language policies in South East Asian countries. In C.Brock \& \& L.P. Symaco (Eds.). Education in South East Asia. Oxford: Symposium Books.

World Bank (2003). “Chad-Education Sector Reform Project (PARSET)” Project Appraisal Document, Report No. 23797. 
FrANCISCO PERLAS DUMANIG, MAYA KHEMLANI DAVID AND LORRAINE SYMACO

World Bank (2012). World Development Indicators. Available at: http://data.worldbank.org/indicator/BX.KLT.DINV.CD.WD [Accessed 21 June 2012].

World Commission on Environment and Development (1987). Our common future. New York: United Nations.

Young, C. (2002) First language first: Literacy education for the future in a multilingual Philippine society. International Journal of Bilingual Education and Bilingualism, 5 (4), 221-232. 